\title{
Aromatasehemmere til unge kvinner?
}

At medikamenter benyttes på andre enn godkjente indikasjoner, er vanlig. I en studie fra USA om forskrivning av 160 vanlige medikamenter var $21 \%$ på ikke-godkjent indikasjon, hvorav $73 \%$ hadde liten eller ingen vitenskapelig støtte (1). Forskrivning av medikamenter på ikke-godkjent indikasjon er nylig beskrevet i Tidsskriftet (2). I dette nummer presenteres en oversikt over bruk av aromatasehemmere til ovulasjonsinduksjon (3). I tillegg til ikke å være godkjent er dette ifølge Felleskatalogen kontraindisert.

En lege kan i prinsippet forskrive et legemiddel på hvilken som helst indikasjon forutsatt at det er innenfor forsvarlighetsbegrepet $i$ helsepersonelloven og at informasjonsplikten overfor pasientene er vel ivaretatt. Legers frihet til forskrivning på ikke-godkjent indikasjon kan ha fordeler ved at det gir mulighet for innovativ klinisk praksis når annen behandling ikke har hatt ønsket effekt, og det gir tidlig tilgang på potensielt effektive medikamenter. Imidlertid kan slik forskrivning også ha negative konsekvenser, siden sikkerhet og effekt ikke er skikkelig vurdert.

Polycystisk ovarie-syndrom med anovulatorisk infertilitet forekommer ofte, og førstelinjebehandling er klomifen. Klomifen gir ovulasjon i $75 \%$ av tilfellene, graviditetsfrekvens på $43 \%$ og kumulert levende fødselsrate etter 12 måneder på 56 \% (4). Forskjellen i oppnådd ovulasjons- og graviditetsrate kan skyldes antiøstrogeneffekt av klomifen på cervixsekretet og endometriet. Andre behandlingsalternativer er ofte kostbare, invasive og/eller mer kompliserte. Derfor er nye og enkle behandlingsmuligheter ønskelige. Et slikt alternativ finnes kanskje $\mathrm{i}$ aromatasehemmere som benyttes $\mathrm{i}$ behandling av hormonreseptorpositiv cancer mammae hos postmenopausale pasienter.

Aromatase konverterer testosteron til østradiol og androstendion til østron. De ikke-steroide aromatasehemmerne letrozol og anastrozol virker ved kompetitiv binding til aromatase. Resultatet er redusert syntese av østrogen, og fordi tilbakekoblingsmekanismen er intakt, vil det hos premenopausale kvinner medføre økt utskilling av follikkelstimulerende hormon (FSH) og luteiniserende hormon (LH) fra hypofysen. I motsetning til klomifen har aromatasehemmere ingen antiøstrogen effekt. På grunn av sin virkningsmekanisme kan aromatasehemmere være et mulig behandlingsalternativ ved flere benigne tilstander hos premenopausale kvinner: ovulasjonsinduksjon ved anovulatorisk infertilitet, follikkelstimulering ved assistert befruktning, endometriose og myoma uteri. Imidlertid er letrozol teratogent i dyrestudier, og det finnes ikke studier på gravide kvinner. På grunn av kort halveringstid vil letrozol gitt i tidlig follikkelfase være ute av sirkulasjonen før eventuell implantasjon av et embryo. Det er derfor gjort flere studier for å vurdere effekten på infertile kvinner (5).

I 2005 ble det på en kongress presentert en studie som påviste økt forekomst av hjerte- og skjelettmisdannelser hos barn født av kvinner som hadde brukt letrozol. Den totale forekomsten av misdannelser i studie- og kontrollgruppen var den samme. Fabrikanten gikk da ut med en presisering om at letrozol ikke skal brukes på premenopausale kvinner, og i Felleskatalogen er premenopausal hormonstatus og graviditet oppført som kontraindikasjoner. Studien ble senere sterkt kritisert for å ha dårlig kvalitet, og året etter kom det en ny studie der man sammenliknet letrozol og klomifen til ovulasjonsinduksjon med henblikk på forekomst av misdannelser $(6,7)$. Her var forekomsten av hjertemisdannelser signifikant lavere blant barn født av kvinner behandlet med letrozol sammenliknet med barn født av kvinner som hadde fått klomifen. Også den totale forekomsten av alvorlige misdannelser var lavest i letrozolgruppen.

Myoma uteri og endometriose er østrogenavhengige tilstander, og i begge tilfeller er det påvist økt aromataseaktivitet sammenliknet med normalt myometrium eller endometrium. Behandling med aromatasehemmere kunne derfor forventes å ha positiv effekt, hvilket er bekreftet i små studier $(8,9)$.

Når fabrikanten anser et medikament som kontraindisert på spesielle indikasjoner, må kravet til forsvarlighet settes særlig høyt dersom man allikevel ønsker å forsøke det. Er den vitenskapelige dokumentasjonen på at medikamentet kan anses som «sikkert», tung eller overbevisende nok? På indikasjonen ovulasjonsinduksjon med aromatasehemmer foreligger det to studier med motstridende resultat med hensyn til risiko for misdannelser, den ene av klart bedre kvalitet enn den andre. Alvorlige medfødte misdannelser er relativt sjeldne, og begge studiene inkluderer få pasienter. Dokumentasjonen på sikkerhet er derfor dårlig vedrørende bruk av aromatasehemmere til ovulasjonsinduksjon. Dersom dette skal forsøkes i Norge, bør det skje som ledd i kliniske studier med den kvalitetssikring av protokoll og pasientinformasjon det innebærer. Dersom aromatasehemmer ønskes forsøkt på pasienter med endometriose eller myoma uteri uten at det foreligger ønske om å bli gravid, kan man samtidig bruke ikke-hormonell antikonsepsjon eller gestagenspiral. Allikevel må pasienten få nøye informasjon, og denne bør journalføres.

\section{Tom Tanbo}

tom.tanbo@rikshospitalet.no

Tom Gunnar Tanbo (f. 1949) er dr.med. og spesialist i fødselshjelp og kvinnesykdommer. Han er leder av Nasjonalt kompetansesenter for kvinnehelse og er professor II ved Universitetet i Oslo.

\section{Litteratur}

1. Radley DC, Finkelstein SN, Stafford RS. Off-label prescribing among officebased physicians. Arch Intern Med 2006; 166: 1021-6.

2. Raknes G. Gamle legemidler, nye muligheter. Tidsskr Nor Legeforen 2008; 128 $62-5$

3. Ekerhovd E. Ovulasjonsinduksjon ved bruk av letrozol. Tidsskr Nor Legeforen 2009; 129: 412-5

4. Imani B, Eijkemans MJ, te Velde ER et al. A nomogram to predict the probability of live birth after clomiphene citrate induction of ovulation in normogonadotropic oligoamenorrheic infertility. Fertil Steril 2002; 77: $91-7$

5. Requena A, Herrero J, Landeras J et al. Use of letrozole in assisted reproduction: a systematic review and meta-analysis. Hum Reprod Update 2008, 14: $571-82$.

6. Tulandi T, Martin J, Al-Fadhli R et al. Congenital malformations among 911 newborns conceived after infertility treatment with letrozole or clomiphene citrate. Fertil Steril 2006; 85: 1761-5.

7. Tulandi T, DeCherney AH. Limiting access to letrozole - is it justified? Fertil Steril 2007; 88: 779-80

8. Gurates B, Parmaksiz C, Kilic G et al. Treatment of symptomatic uterine leiomyoma with letrozole. Reprod Biomed Online 2008; 17: 569-74.

9. Nawathe A, Patwardhan S, Yates D et al. Systematic review of the effects of aromatase inhibitors on pain associated with endometriosis. BJOG 2008; 115 : $818-22$. 